\title{
Legal Protection for Child Victims of Sexual Violence in Indonesia
}

\author{
Rehnalemken Ginting \\ Universitas Sebelas Maret, \\ Surakarta, Jawa Tengah, Indonesia
}

\author{
Lushiana Primasari \\ Universitas Sebelas Maret, \\ Surakarta, Jawa Tengah, Indonesia \\ lushiana_hukumuns@yahoo.com
}

\author{
Rofikah \\ Universitas Sebelas Maret, \\ rofikah00@yahoo.com
}

\begin{abstract}
This article discusses the provisions of legislation governing legal protection for child victims of sexual violence and factors that affect the high number of sexual violence against children in Indonesia. The current case of sexual assault against children continues to increase. In general, the perpetrators are the closest to the victims, such as parents, teachers, neighbors, and relatives. Cases of sexual violence in children are difficult to uncover because the victims are afraid of reporting the sexual violence they experience because of the involvement of the closest people who affect their daily lives. This article aims to find a way to strengthen legal protection for child victims of sexual violence in Indonesia. The research method used is normative method supported by empirical research. The data used are primary data and secondary data. The instruments used are focus group discussions and in-depth interviews. Data were analyzed qualitatively and presented descriptively. The policy implication of this research is the protection policy for child victims of sexual violence that refers to the rights of children as victims of sexual violence and the involvement of the role of the community in the recovery of trauma. This article concludes that the government is concerned with the legal protection of child victims of sexual violence, this is based on the legal instruments underlying the abolition of sexual violence. Factors that lead to high levels of sexual violence are social media, social environment, and neglect of parents. Legal protection of child victims of sexual violence in Indonesia is expected to create an integrated system of child protection for victims of sexual violence involving community participation.
\end{abstract}

Keywords-Child victims; Legal protection; Sexual violence;

\section{INTRODUCTION}

Cases of child sexual abuse continue to increase. Children are very vulnerable to being victims of crime. The case of sexual assault against the child seems to be an iceberg phenomenon, appearing slightly on the summit, but there is indeed a large chunk in it. Few cases of sexual violence against children are reported to the authorities, this is due to various factors, such as the embarrassment of sexual violence that befalls the child as a disgrace in society, not sure that the report will be processed or because it is under threat of the perpetrator, so many cases of sexual violence against children are not revealed.
In general, perpetrators of sexual violence against children are the nearest victims such as parents, teachers, neighbours, friends and playmates. Cases of sexual violence in children are difficult to uncover because of the fear of victims to report the sexual violence they experienced as it involved the closest people who affect the daily lives of the victims.

Based on KPAI data, in 2011 data of children who became victims of sexual violence, rape, abuse, sodomy, paedophilia and others reached 216 cases, 2012 reached 412 cases, 2013 reached 343 cases, 2014 reached 656 cases, 2015 reached 218 cases and 2016 reached 120 cases. This shows that cases of sexual violence against children reach high numbers, so it needs to be the attention of many parties, both government, law enforcement officers, education practitioners, nongovernmental organizations, parents and the community.

The case of sexual assault against children is quite sticking out in the media as the sexual violence perpetrated by Jakarta International School (JIS) teachers against some of the victims. The rise of this case is a concern of many parties because the school which is considered as an educational institution which is a safe place for students is precisely a place that potentially occurs sexual violence against children.

Another case that is not less public attention is the case of "Emon" who sexually harassed dozens of children in Sukabumi. The majority victims are children who are in physical and psychic development. Sexual violence affecting a child is feared will cause prolonged trauma that aka brought the child into adulthood, thus disrupted the development of children both physical and psychological.

In cases if sexual violence against children continue to be left, it will cause a domino effect that is not only harmful to the physical and psychological development of children but the further impact on the future of Indonesian children as the next generation of the nation. The next generation of nations that should have a childhood by playing and going to school but must be violated by sexual violence committed by the people closest to the children.

Handling of cases of sexual violence against children can not involve law enforcement officers only, but it needs synergy between various parties so as to solve cases of sexual violence against children completely. The effort is also 
accompanied by legal protection and trauma recovery in children so that children who become victims of sexual violence can experience the recovery of psychic trauma as well as guaranteed their rights in the legal process that goes hand in hand with the settlement of the case.

In a case involving children, in particular in this case, sexual violence is necessary to provide special protection to children victims of sexual violence such as rehabilitation, information on case development, protection from identity coverage to avoiding stigmatization or labelling and the provision of the guarantee of safety for victim witnesses. The policy implications of this research are that the protection of children who are victims of sexual violence, and the rights of children as victims of sexual violence, and involving the role of the community in the recovery of trauma. This study aims to examine factors that encourage high rates of sexual violence against children in Indonesia and legal protection against child victims of sexual violence.

\section{ANALYSIS}

\section{A. Children Sexual Violence Triggering Factors}

conditions around them because it is a serious crime since its impact on victims brings trauma to life for a long period of time, even a lifetime. Children who are victims of sexual violence come from various social backgrounds and various age ranges. Understanding the child according to Article 1 of Law of the Republic of Indonesia Number 35 Year 2014 on the Amendment of Law Number 23 Year 2002 on Child Protection, which referred to the child as a person who is not yet 18 (eighteen) years of age, including a child who is still in the womb. Children are vulnerable to violence. The notion of violence itself constitutes all forms of physical and/or emotional abuse, sexual abuse, neglect or exploitation commercially or otherwise, resulting in a real or potential disruption to development, health, survival or dignity in the context of responsible relationships, beliefs, or power. Violence in children involves not only physical abuse or sexual abuse, but it can be more than that. The parental neglect of her child also includes a form of child abuse. Types of child abuse are, namely: neglect of children, physical violence, psychic violence, sexual violence.

Sexual violence is a form of sexual contact or another form of sexual unwantedness. Sexual violence is usually accompanied by psychological or physical pressure. Several types of sexual violence according to the National Commission on Women (Komnas Perempuan) are:

1. rape assault in the form of coercion of sexual intercourse by using the penis towards the vagina, anus or mouth of the victim

2. Sexual intimidation that includes threats or attempted rape

3. sexual harassment of sexual acts by physical or nonphysical touch with the target of sexual or sexual organs of the victim.
4. sexual exploitation

5. trafficking of women for sexual purposes

6. forced prostitution.

7. sexual slavery

8. coercion of marriage, including hanging

9. coercion of pregnancy

10. coercion of abortion

11. coercion of contraception and sterilization

12. sexual torture

13. Inhuman and sexual punishment

14. the practice of sexual traditions that harm or discriminate against women

15. Sexual control, including through discriminatory rules, grounded in morality and religion

Of the several types of sexual violence, some occur in children as victims. Children are very vulnerable to being victims of crime. With a weak physical, children will be difficult to resist sexual violence, especially if done by adults from the nearest environment. Violence against children is a tangible and frequent condition, in fact, even more, frequent cases than those reported on the surface. Children rarely admit directly that they have experienced violence and become victims. Situations under threat, an unfriendly environment, or an exclusive child and parent relationship will cause a child to hold an event, reluctant to tell a story until it is no longer able to hide the event when a child experiences an accident such as a pregnancy, a physical disability, a plunge to the same peoples and other conspicuous cases a child chooses to make his own settlement, thus hoping that the closest people will be able to identify early victims and children who are experiencing violence.

One reason for the lack of reports of child abuse that is actually the case is that often emotional violence is not reported, as it is not the result of physical violence. Violence in children can have a prolonged impact, including:

1. The victim feels a grudge against the perpetrator, fear of marriage, inferior, and trauma due to sexual exploitation, even though they are now adults or even married.

2. Sexual exploitation experienced during childhood may be a cause of involvement in prostitution.

3. If sexual violence occurs in a small child, adverse effects may include, among other things, usually not bedwetting, incontinence, sleeplessness, unwarranted anxiety, or even physical symptoms such as abdominal pain or skin problems.

Children as sexual violence need special attention. Regarding the meaning of the victims, as regulated in Article 1 Sub-Article 3 of the Law of the Republic of Indonesia Number 31 Year 2014 concerning Amendment to Law Number 13 Year 2006 concerning the Protection of Witnesses and Victims, the victim is a person suffering physical, mental 
and/or loss economic consequences of a crime. When viewed from the perspective of the victim's own responsibility then Stephen Schafer put the victim's typology into seven forms, namely:

1. Unrelated victims are those who have no relationship with the perpetrator and become victims because of potential. For that, from the aspect of responsibility is completely on the side of the victim.

2. Provocative victims are victims caused by the role of the victim to trigger a crime. Therefore, the aspect of responsibility lies in the victims and the perpetrators together.

3. Participating victims the nature of the act of the victim unconsciously can encourage the perpetrator to commit a crime, and the aspect of liability is entirely in the perpetrator.

4. Biologically weak victims are crimes caused by the physical state of the victims such as women, children, and elderly people are potential victims of crime. Viewed from the aspect of responsibility that lies on the community or local government, the crimes occur because the community or local government can not provide protection to victims who are helpless.

5. Socially weak victims who are not noticed by the community concerned as homeless with a weak social position. For that, his full responsibility lies on the villain or the community.

6. Self-victimizing victims are victims of self-committed crimes or non-victim crimes. For that, responsibility lies on the victim as well as perpetrators of crime.

7. Political victims are victims because of their political opponents. Sociologically, this victim cannot be accounted for unless there is a change of political constellation.

The child whoos weak and helpless makes himself vulnerable to become victims of sexual harassment. The rise of abuse cases against children is also influenced by the release of information. In addition to this, things that cause vulnerable children include:

1. Families that are not harmonious;

2. Parents who abuse addictive substances or suffer from mental disorders;

3. Abandonment or neglect;

4. Inappropriate or aggressive behaviour in the classroom, failing or being less accountable to the school;

5. Limited social skills;

6. Affected societal environment, eg friends who use alcohol or drugs and engage in other risky behaviours;

7. Low economic status; and

8. Behavior that indicates the use of drugs, alcohol or cigarettes at an early age
These factors are the factors that trigger the occurrence of sexual violence against children. The current development of technology and information contributes to the increasing sexual violence against children. Perpetrators of sexual violence against children are not only adults but also children who are affected by what they see in social media. The perpetrators of sexual violence against children not only do their actions because they are influenced by social media, they also disseminates the act of sexual violence through social media, so that the action is seen by many people. Tthis would be a double suffering for child victims of sexual violence: victims of sexual violence and being embarrassed as the action is spread through social media.

\section{B. Legal Protection for Children Victims of Sexual Violence}

The child as a victim of sexual violence suffers physically and psychologically so that he must be protected, because sexual violence will cause fear to the child and feelings of public fear to know the incident that happened to him (because this incident is a disgrace for himself and his family), or the victim refuses to indemnify because it is feared that the process will become longer and protracted which can result in the onset of prolonged suffering.

The importance of the victim recovery as an effort to balance the psychological condition of the affected victim, rightly stated by Muladi that crime victims need to be protected because:

1. Society is regarded as a form of a system of institutionalized trust. This belief is integrated through norms expressed within the institutional structure. The occurrence of crimes against the victim will mean the destruction of the belief system so that the arrangement of criminal law and other law concerning the victim will serve as a means of returning the belief system.

2. The existence of social contract arguments and social solidarity as it may be said to monopolize all social reactions to crime and prohibit actions that are personal. Therefore, if there is a crime victim, the state is concerned with the needs of the victims by improving the service and the regulation of rights.

3. Protection of victims who are usually associated with one of the purposes of crime, namely the settlement of the conflict. With the settlement of conflicts generated by the crime will restore balance and bring peace to the community.

In Article 5 Paragraph (1) of the Law of the Republic of Indonesia Number 31 The year 2014 concerning Amendment to Law Number 13 The year 2006 concerning the Protection of Witnesses and Victims, the victims are entitled to:

a. obtain protection of his or her personal, family, and property, and is free of threats relating to the testimony that he or she will be, or has given;

b. participate in the process of selecting and determining the form of protection and security support;

c. provide information without pressure;

d. got translator; 
e. free from trap questions;

f. get information about case progress;

g. be informed of court decisions;

h. be informed in the event that the convicted person is released;

i. concealed identity;

j. $\quad$ get a new identity;

k. have temporary residence;

1. get a new residence;

m. obtain reimbursement of transportation costs as needed;

n. get legal advice;

o. receive temporary living expenses up to the time limit Protection ends; and/or

\section{p. get mentoring.}

Further as stipulated in Article 6 Paragraph (1) victims of gross human rights violations, victims of terrorism, victims of trafficking in persons, victims of criminal acts of torture, victims of sexual violence, and victims of serious maltreatment, in addition to the right referred to in Article 5, are also entitled to a. medical assistance; and b. psychosocial and psychological rehabilitation assistance. Thus, children who become victims of sexual violence also need medical assistance and psychosocial rehabilitation.

Efforts to protect children victims of sexual violence began to receive government attention, it can be seen from the existing legal instruments underlying the abolition of violence against children, among others:

1. The 1945 Constitution Article 28b paragraph 2, every child shall have the right to survive, grow, and develop and shall be entitled to protection from violence and discrimination.

2. Law No. 7/1984 on the Ratification of the Convention on the Elimination of All Forms of Discrimination Against Women (Convention On The Elimination of All Forms of Discrimination Against Women)

3. Law Number 35 The year 2014 regarding the amendment to Law Number 23 The year 2002 regarding Child Protection (BAL)

4. Law Number 23 The year 2004 regarding Elimination of Domestic Violence (UU PKDRT)

5. Law Number 44 The year 2008 regarding Pornography

6. Law Number 21 The year 2007 concerning the Eradication of Crime of Trafficking in Persons (UU PTPPO)

7. Law Number 11 The year 2012 regarding the Law on Child Criminal Justice System.
8. Law Number 19 The year 2016 regarding the amendment to Law Number 11 The year 2008 regarding Information and Electronic Transactions (UU ITE)

9. Law Number 31 The year 2014 regarding the amendment to Law Number 13 The year 2006 concerning Protection of Witness and Victim (Act on PSK)

10. Supreme Court Regulation No. 3 of 2017 concerning Guidelines on Trial of Women Cases against the Law.

Several areas in Indonesia have regulated child protection in Regional Regulations, such as Surakarta City Local Regulation No. 4 of 2012 on Child Protection. Surakarta became one of the pilot cities in terms of child protection, one with the establishment of Integrated Service of Women and Children Surakarta (PTPAS) Services provided by PTPAS to child victims of sexual violence. Handling action to the victim may be provided by the officer if the case has been reported to this institution. After a complaint of violent cases, the officer then finds out whether there is actually a violent incident by confirming to the perpetrator or the person knowing the violence. If at the time of a complaint of violence cases the victim came to the office, then the victim can be immediately given further treatment. However, if the victim does not participate, the officer will visit the house or place of violence to confirm. Visits conducted by officers other than to ensure violent incidents are actually taking place also aim to identify the circumstances of the victim and the environmental conditions of the victim's residence which may be a support or threat to the victim.

After the officer receives a complaint of violence cases, the officer conducts case assessment by taking notes and observing the victim to ensure that violence has occurred. Case assessment was conducted on the victim with the aim of assessing the physical, safety and psychological status of the victim. Assessment is done by asking questions to the victim about the victim's physical condition as well as the psychological state of the victim and his security. The assessment is used to determine the attitude or subsequent action against the victim. Based on the result of the case assessment the officer conducted a case coordination meeting. PTPAS is committed to providing services and assistance to women and children victims of violence in the form of: Consultation/Psychological Examination, Medical/Health Services, Legal Process Assistance, Provision of Safe House (Shelter), Repatriation

After the victim can be restored to its original condition, the victim is returned to his family by monitoring or supervision by UPT PTPAS. Victims are monitored daily activities, such as associating with whom, how victims interact with others, whether the victim still shows symptoms of depression, or whether the victim's environment still has the potential to make victims experience violence. In addition to receiving reports from the cadres, officers also made visits to the victim's home to ensure the progress of the victim's situation.

After knowing the suffering of child victims of sexual violence as a result of sexual violence that has been experienced, it has become the government's obligation to 
provide protection to child victims of violence that are implemented in the legislation as a legal product in favour of child victims of sexual violence. The compensation for victims of sexual violence must be proportional to the origin of the violence and the consequences suffered by the victim. Replace such losses include:

\section{Restitution}

Restitution is defined as the return of the situation before the victim suffers losses due to the crime he experienced.

\section{Compensation}

Compensation must be able to recover the losses suffered by the victim. The compensation given to the victim of sexual violence must be based on the secrecy of the victim,

\section{Satisfaction}

This satisfaction is manifested as an effort to recover the victims of stigmatization and stereotypes received after the sexual violence experienced so that the public understands that there should be no further victimization to the victim Rehabilitation

\section{Rehabilitation}

Rehabilitation is intended to provide primary services for victims in order to assist victims to continue their lives in a humane way.

\section{Guarantees of non-repetition of crime}

The government should be able to identify the root causes of sexual violence and make recommendations to address the problem.

Integrated protection and synergy of all parties related to the protection of children victims of sexual violence, is expected to reduce or even eliminate the occurrence of sexual violence against children. Law enforcement in cases of sexual violence against children needs to be optimized, but prevention efforts need to be given more attention so that no more victims of sexual violence against children.

\section{CONCLUSION}

1. The child who is weak and helpless makes himself vulnerable to become a victim of sexual harassment. In addition to this, things that cause vulnerable children include: families that are not harmonious; parents who abuse addictive substances or suffer from mental disorders; parental neglect; inappropriate or aggressive behavior in the classroom, failing or being less accountable to the school; limited social skills; affected societal environment, eg friends who use alcohol or drugs and engage in other risky behaviors; low economic status; and behavior showing the use of drugs, alcohol or cigarettes at an early age misuses social media and information technology

2. Efforts to protect children victims of sexual violence began to receive government attention, it can be seen from the existing legal instruments underlying the abolition of violence against children, namely: 1945 Constitution Article 28b paragraph 2, Every child has the right to survival, growth, and develops and is entitled to protection from violence and discrimination; Law Number 7 Year 1984 on Ratification of the Convention Concerning the Elimination of All Forms of Discrimination Against Women; Law Number 35 Year 2014 regarding the amendment to Law Number 23 Year 2002 regarding Child Protection (LoGA); Law Number 23 Year 2004 on the Elimination of Domestic Violence (UU PKDRT); Law Number 44 Year 2008 regarding Pornography; Law Number 21 Year 2007 on the Eradication of Crime of Trafficking in Persons (UU PTPPO); Law Number 11 Year 2012 regarding the Law on Child Criminal Justice System; Law Number 19 Year 2016 regarding the amendment to Law Number 11 Year 2008 regarding Information and Electronic Transactions (UU ITE); Law Number 31 Year 2014 regarding the amendment to Law Number 13 Year 2006 concerning Protection of Witness and Victim (UU PSK); Supreme Court Regulation No. 3 of 2017 concerning the Guidance on Judging Women Cases Against the Law. The compensation for victims of sexual violence must be proportional to the origin of the violence and the consequences suffered by the victim. The replacement of such losses include restitution, compensation, satisfaction, rehabilitation, and guarantees non-repetition of crime

\section{REFERENCES}

[1] Didik M. Arief Mansur dan Elisatris Gultom. (2007). Urgensi Perlindungan Korban Kejahatan antara Norma dan Realita. Jakarta: PT. Raja Grafindo Persada

[2] Komisi Perlindungan Anak Indonesia. (2017). Rincian Data Kasus Berdasarkan KlasterPerlindungan Anak, 20112016.http://bankdata.kpai.go.id/tabulasi-data/data-kasuspertahun/rincian-data-kasus-berdasarkan-klaster-perlindungan-anak2011-2016

[3] KomnasPerempuan.JenisKekerasanSeksual.http://www.komnasperempu an.or.id/wpcntent/uploads/2013/12/15-Jenis-KekerasanSeksual_2013.pdf

[4] Rena Yulia. (2013). Viktimologi Perlindungan Hukum Terhadap Korban Kejahatan.Yogyakarta: Graha Ilmu 